\title{
In vitro adventitious organogenesis in Ajania pacifica (Nakai) Bremer et Humphries
}

\author{
Alicja TymoszuK *, Matgorzata AntKowiak \\ UTP University of Science and Technology, Faculty of Agronomy and Biotechnology, Department of Agrometeorology, \\ Plant Irrigation and Horticulture, Laboratory of Ornamental Plants and Vegetable Crops, Bydgoszcz, Poland
}

\begin{abstract}
This study tested the effects of explant type, medium composition, and cultivar on in vitro regeneration of callus, shoots, and roots in Ajania pacifica (Nakai) Bremer et Humphries. In Experiment 1, "Bea", "Bess" and "Bengo" ex vitro internodes and ex vitro leaf explants were inoculated on a modified MS (Murashige and Skoog, 1962) medium with $3 \mathrm{mg} \cdot \mathrm{dm}^{-3}$ benzylaminopurine (BAP) and $0.5 \mathrm{mg} \cdot \mathrm{dm}^{-3}$ indole-3-acetic acid (IAA). The share of internodes and leaf explants that proliferated callus were $92-96 \%$ and $56-100 \%$, respectively. Adventitious shoot regeneration was observed on "Bengo" and "Bea" internodes (1.12 and 0.32 shoots, respectively, per explant inoculated) and on "Bea" leaf explants (0.2 shoots per explant inoculated). In Experiment 2, "Silver and Gold" ex vitro leaf explants were placed on a modified MS medium with the addition of auxin and cytokinin: $0,0.5$, and $1 \mathrm{mg} \cdot \mathrm{dm}^{-3}$ 1-naphthaleneacetic acid (NAA) or thidiazuron (TDZ) or BAP. Callogenesis was not reported only in the medium without plant growth regulators. Adventitious roots were seen to regenerate on media without plant growth regulators and with 0.5 or $1 \mathrm{mg} \cdot \mathrm{dm}^{-3} \mathrm{NAA}(0.47,1.2$, and 2.93 roots per explant inoculated, respectively). In Experiment 3, "Bea", "Bess" and "Bengo" ex vivo internodes were inoculated on a modified MS medium with $0.6 \mathrm{mg} \cdot \mathrm{dm}^{-3}$ BAP and $2 \mathrm{mg} \cdot \mathrm{dm}^{-3}$ IAA. All explants produced calli. Shoots regenerated only on "Bengo" internodes (1.3 shoots per explant inoculated). These results confirmed the possibility of in vitro callogenesis and adventitious organogenesis in Ajania pacifica.
\end{abstract}

Key words: adventitious root, adventitious shoot, callus, internode, leaf explant, micropropagation

\section{Introduction}

Ajania pacifica (Nakai) Bremer et Humphries is becoming increasingly popular worldwide as an alternative to chrysanthemum. The Ajania genus belongs to the Asteraceae family and includes more than 30 species (Bremer and Humphries, 1993) that are valuable as ornamental (Ajania pacifica [Nakai] Bremer et Humphries, synonym Pacific chrysanthemum, formerly Dendranthema pacificum and Chrysanthemum pacificum) or medicinal plants (Ajania fruticulosa [Ledeb.] Polj.) (Hao et al., 1999; Meng et al., 2001; Zhao et al., 2008). Ajania pacifica (Nakai) Bremer et Humphries is a perennial that originated from Central Asia and Eastern Europe. The species forms many auxiliary shoots with dense green and silver-colored leaves that remaining decora- tive beyond the flowering period in autumn (Bremer and Humphries, 1993).

Ajania is propagated mainly in vivo from shoot cuttings and cultivated as a pot plant or for cut flowers. With regard to in vitro propagation of Ajania pacifica, to date, only the simple and cost-efficient single-node method has been used (Zalewska et al., 2012). Important research results concerning synthetic seeds and cryopreservation of this species for medium- and long-term storage have been recently published (Kulus and Abratowska 2017). In the scientific literature, there are no reports of research concerning callogenesis and adventitious organogenesis in this species; however, reports of such results are potentially important not only from the scientific point of view, but also for plant production and

\footnotetext{
* Corresponding author: UTP University of Science and Technology, Faculty of Agronomy and Biotechnology, Bydgoszcz, Poland; e-mail: alicja.tymoszuk@utp.edu.pl
} 
breeding programs. It is worth mentioning that mutation induction that is combined with in vitro regeneration of adventitious shoots is a very common breeding technique in Chrysanthemum $\times$ grandiflorum/Ramat./ Kitam, which is a species closely related to Ajania pacifica ( $\mathrm{Za}-$ lewska et al., 2010; Zalewska et al., 2011b). Ajania may become an interesting alternative for chrysanthemum, especially because the cultivation of both species can be carried out simultaneously. Furthermore, the technique of in vitro adventitious bud regeneration is a well-known source of somaclonal variation in chrysanthemum (Zalewska et al., 2007; Teixeira da Silva and Kulus, 2014) and, possibly, also in Ajania. This variation could have positive outcomes in terms of providing new cultivars.

Micropropagation is a valuable tool for mass production of plants under laboratory conditions. Over time, several micropropagation techniques have been developed (Kulus, 2015a), with adventitious organogenesis being one of the most effective and efficient methods (Lema-Rumińska and Kulus, 2014). In plants, in vitro adventitious organogenesis is affected by many factors, such as plant growth regulators, the genotype (Park et al., 2005; Park et al., 2007; Tymoszuk and Zalewska, 2014a), the explant type (Lu et al., 1990), the division and inoculation position (Gahan and George, 2008; Tymoszuk and Zalewska, 2014b), as well as levels of endogenous growth regulators (Kumar and Kanwar, 2006). The explants excised from young organs regenerate the callus faster (Gahan and George, 2008) and produce more shoots than the explants from older parts (Lu et al., 1990; Nakano et al., 1994). In vitro adventitious organogenesis strongly depends on the type and the concentration of plant growth regulators, especially auxins and cytokinins, added to the medium (Kulus, 2014). Most often, a high concentration of cytokinins and a low concentration of auxins induce the formation of shoots, and a high concentration of auxins and a low concentration of cytokinins induce rhizogenesis (Park et al., 2005; Park et al., 2007; Tymoszuk and Zalewska, 2014). Thus far, none of mentioned factors have been analyzed in Ajania pacifica.

The aim of the present research was to determine the effect of plant growth regulators, the explant type, and cultivars on callogenesis and the regeneration of adventitious shoots and roots in in vitro cultures of Ajania pacifica.

\section{Materials and methods}

Ajania pacifica (Nakai) Bremer et Humphries "Silver and Gold", "Bess", as well as "Bea" and "Bengo" (representing the Bellania group) were used in the experiments. These four cultivars were bred by Kientzler Jungpflanzen (Kientzler GmbH \& Co. KG, Germany).

In all of the experiments, the MS (Murashige and Skoog, 1962) medium was used, albeit in a modified form obtained by increasing the content of calcium and iron by $50 \%\left(660 \mathrm{mg} \cdot \mathrm{dm}^{-3} \mathrm{CaCl}_{2} \cdot 2 \mathrm{H}_{2} \mathrm{O}, 41.7 \mathrm{mg} \cdot \mathrm{dm}^{-3}\right.$ $\mathrm{FeSO}_{4} \cdot 7 \mathrm{H}_{2} \mathrm{O}$ and $\left.55.8 \mathrm{mg} \cdot \mathrm{dm}^{-3} \mathrm{Na}_{2} \mathrm{EDTA} \cdot 2 \mathrm{H}_{2} \mathrm{O}\right)$. The media were solidified with $0.8 \%(\mathrm{w} / \mathrm{v})$ Plant Propagation LAB-AGAR $^{\mathrm{TM}}$ (BIOCORP, Poland) with all the nutrients added prior to autoclaving. The medium $\mathrm{pH}$ was adjusted to 5.8. Tissue cultures were kept in $350 \mathrm{ml}$ jars with 40 $\mathrm{ml}$ of the medium.

In vitro cultures were maintained at $24 \pm 2^{\circ} \mathrm{C}$ in a growth chamber that was exposed to a 16 -hour photoperiod by using Philips TLD 36W/54 fluorescent lamps that emitted cool daylight. The quantum irradiation intensity was set at approximately $35 \mu \mathrm{mol} \cdot \mathrm{m}^{-2} \cdot \mathrm{s}^{-1}$.

Experiment 1. Effect of ex vitro explant type and cultivar on the regeneration of callus and adventitious shoots

The MS medium was used, as described earlier, after being modified with an increase in the concentration of thiamine to $0.4 \mathrm{mg} \cdot \mathrm{dm}^{-3}$ and decrease in the content of sucrose to $10 \mathrm{~g} \cdot \mathrm{dm}^{-3}$. In addition, plant growth regulators, that is, $3 \mathrm{mg} \cdot \mathrm{dm}^{-3}$ benzylaminopurine (BAP; Sigma-Aldrich) and $0.5 \mathrm{mg} \cdot \mathrm{dm}^{-3}$ indole-3-acetic acid (IAA; Sigma-Aldrich) were added (Jerzy and Lubomski, 1992). Whole leaf (blade with petiole) and internode explants were derived from "Bengo", "Bea" and "Bess" microcuttings propagated in vitro using a single-node method on the MS medium. Leaf explants ( $2 \mathrm{~cm}$-in-length) were polarly inoculated, $0.5-\mathrm{cm}$ fragments of internodes were horizontally inoculated. For each experimental treatment, five replications were applied; five explants in each.

Experiment 2. Effect of plant growth regulators on the regeneration of callus and adventitious roots on ex vitro leaf explants in Ajania "Silver" and "Gold"

The "Silver and Gold" cultivar has very short internodes, and its usage in Experiment 1 was impossible. We used the MS medium supplemented with: $30 \mathrm{~g} \cdot \mathrm{dm}^{-3}$ sucrose, auxin $0,0.5$, or $1 \mathrm{mg} \cdot \mathrm{dm}^{-3} 1$-naphthaleneacetic acid (NAA; Sigma-Aldrich), and cytokinin 0, 0.5, or 
$1 \mathrm{mg} \cdot \mathrm{dm}^{-3}$ thidiazuron (TDZ; Sigma-Aldrich) or BAP. Whole leaves (2-cm-in-length) were polarly inoculated as explants. For each experimental treatment, three replications were applied, and there were five explants each.

Experiment 3. Effect of cultivar on the regeneration of callus and adventitious shoots on ex vivo internodes The MS medium supplemented with $30 \mathrm{~g} \cdot \mathrm{dm}^{-3}$ sucrose and $0.6 \mathrm{mg} \cdot \mathrm{dm}^{-3}$ BAP and $2 \mathrm{mg} \cdot \mathrm{dm}^{-3}$ IAA was used. EX vivo internodes $(1 \mathrm{~cm}$ in length) were collected from "Bengo", "Bea" and "Bess" plants cultivated in the greenhouse. First, the internodes were rinsed under running tap water, placed in $5 \%$ detergent solution for $5 \mathrm{~min}$, and, then, transferred into a $70 \%$ ethanol solution for $5 \mathrm{~s}$. Explants were then incubated in $20 \mathrm{ppm} \mathrm{Ag}$ and $\mathrm{Cu}$ nanocolloid for $10 \mathrm{~min}$. Prior to horizontal inoculation on the medium, the explants were dried on sterile paper. For each experimental treatment, 20 replications were applied, with two explants in each replication.

\section{Parameters analyzed and statistical analysis}

For 10 successive weeks, the dynamics of the shoots and roots regeneration were observed. The regenerated shoots and roots were counted at a magnification of between $0.7 \times 10$ and $4.5 \times 10$ under a stereoscopic microscope MS-Z TRI provided by PRECOPTIC Co. (Poland). The share of the explants regenerating calli, shoots, or roots and the mean number of shoots or roots per explant inoculated were estimated.

The experiments were set up in a completely randomized design. To obtain the normal distribution of the features investigated, the real numerical data $(x)$ for the mean number of shoots and roots were transformed by $\sqrt{x+0.5}$ whereas, for the data expressed as a percentage, the Freeman-Tukey transformation was used. The transformed data were statistically verified using the analysis of variance (ANOVA), and means for the treatment were evaluated with the Tukey test at a significance level of $P=0.05$. Tables with results of experiments $1-3$ provide real untransformed numerical data, with alphabets indicating the homogeneous groups.

\section{Results and discussion}

Experiment 1. Effect of ex vitro explant type and cultivar on the regeneration of callus and adventitious shoots

In the first week of culture, all of the explants grew visually bigger as a result of cytokinin and water intake from the medium. The internodes grew longer and swollen, especially in the region where they were cut. In leaf explants, parts of petioles immersed in the medium increased their volume more than the blades. In the second week, callus regeneration began, initially around the cut region and, later, on the entire surface of internodes and leaf petioles. In the third week, the callus in "Bess" and "Bengo" started to turn yellow and, in the fourth week, they began to go brown. "Bea" proliferated callus more intensively, thereafter yellowing and browning appeared in the fourth and in the fifth week, respectively. Adventitious shoot regeneration occurred via calli and was observed on internodes in "Bengo" and "Bea" (Fig. 1). The first shoots in "Bengo" and in "Bea" appeared in the third and fourth weeks of culture, respectively. Successive formation of shoots in "Bengo" continued until the end of culture. In "Bea", in the seventh and eighth weeks, the number of shoots remained at the same level; however, in subsequent weeks, the regeneration of new shoots progressed, although not as intensively as in "Bengo".

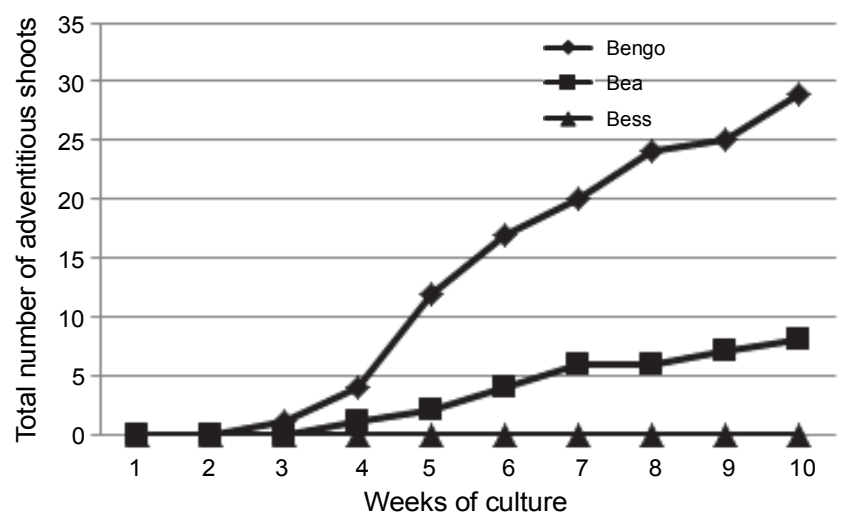

Fig. 1. Dynamics of adventitious shoots regeneration on Ajania "Bengo", "Bea" and "Bess" ex vitro internodes on the modified MS (1962) medium with $3 \mathrm{mg} \cdot \mathrm{dm}^{-3} \mathrm{BAP}$ and $0.5 \mathrm{mg} \cdot \mathrm{dm}^{-3} \mathrm{IAA}$

The regeneration of shoots on leaf explants occurred only in "Bea" (Fig. 2 and Fig. 3). The first shoot appeared in the seventh week of culture, and the regeneration progressed until the ninth week.

There was callus formation on all inoculated leaf explants in "Bea" (Table 1). Internodes proliferating callus accounted for $96 \%$ of the cultures in "Bea" and "Bess", and 92\% in "Bengo". All of these values did not differ significantly. With regard to "Bengo", the callus formed more often on the internodes (92\%) than on the 


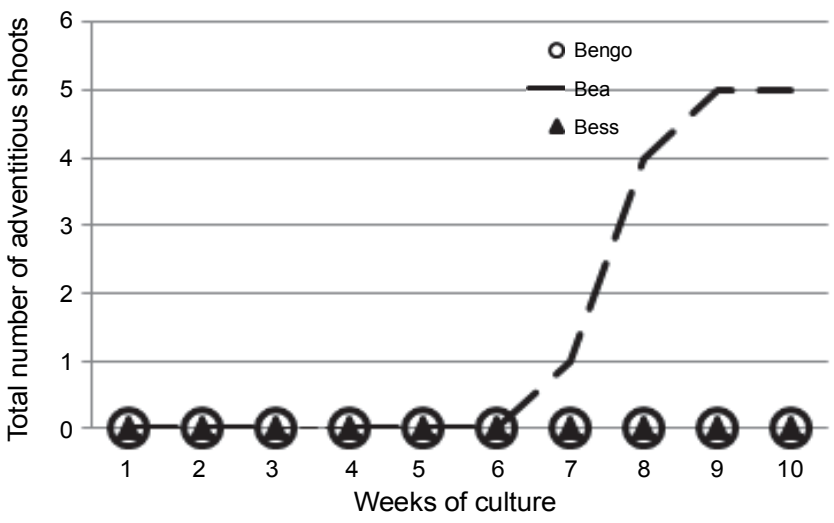

Fig. 2. Dynamics of adventitious shoots regeneration on $e x$ vitro leaf explants of Ajania "Bengo", "Bea" and "Bess" on the modified MS (1962) medium with $3 \mathrm{mg} \cdot \mathrm{dm}^{-3} \mathrm{BAP}$ and $0.5 \mathrm{mg} \cdot \mathrm{dm}^{-3}$ IAA

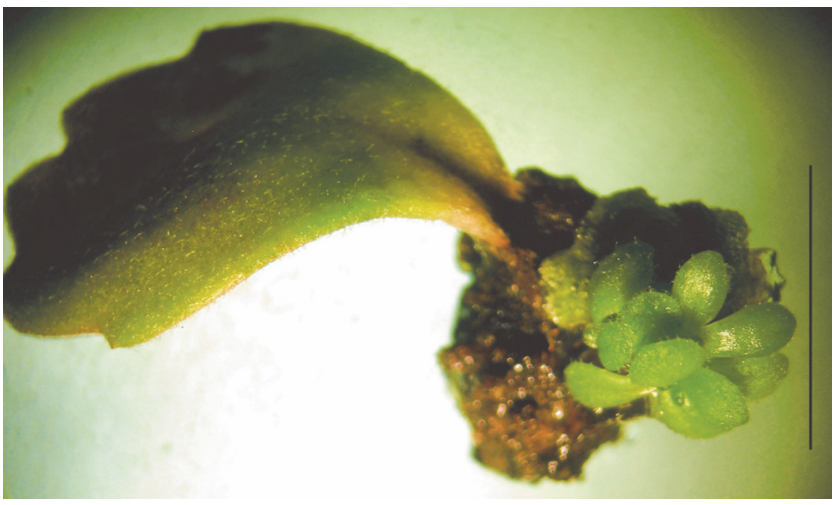

Fig. 3. Callus and adventitious shoots on the ex vitro leaf explant of Ajania "Bea" on the modified MS (1962) medium with $3 \mathrm{mg} \cdot \mathrm{dm}^{-3}$ BAP and $0.5 \mathrm{mg} \cdot \mathrm{dm}^{-3}$ IAA after 10 weeks of culture; $1 \mathrm{bar}=1 \mathrm{~cm}$

leaf explants (56\%). In comparison, the percentage values between the explant type did not differ significantly in "Bea" and "Bess". Approximately $16 \%$ of the inoculated "Bengo" internodes formed adventitious shoots, but the leaves did not form shoots. In "Bea" the percentage of internodes and leaves regenerating shoots was the same (4\%). In "Bess" no regeneration of shoots was observed. Most shoots (1.12 per explant) formed on the internodes in "Bengo". The mean number of shoots per internode and leaf explant inoculated in "Bea" was 0.32 and 0.2 , respectively, and did not differ statistically. In comparison, the explants of "Breeze White" and "Capitola" chrysanthemum ligulate florets inoculated on the same medium formed two shoots on average (Jerzy et al., 2015). The regeneration of adventitious shoots strongly depends on the type of explant used and the cultivar (Park et al., 2005; Park et al., 2007), which was also confirmed in the present experiment. Similarly as with Ajania "Bengo", Zalewska and coworkers (2011a) as well as Miler and Zalewska (2014) observed that the regeneration of adventitious shoots in chrysanthemum cultivars is more effective on internodes than on leaf explants. Explants from different organs and tissues are often unevenly affected by the same plant growth regulators. This may be caused by different levels of endogenous growth regulators as well as the age and the number of cells undergoing regeneration.

Experiment 2. Effect of plant growth regulators on the regeneration of callus and adventitious roots on ex vitro leaf explants in Ajania "Silver" and "Gold"

After the first week of culture, parts of petioles put directly onto the medium increased their volume. In the second week, leaf blades started yellowing, and callus regeneration was noted on the media with the addition of growth regulators. Explants on the MS medium without plant growth regulators did not display callus formation. Direct regeneration of adventitious roots occurred on the modified MS medium without plant growth regulators. Indirect regeneration of adventitious roots was observed on the MS media with auxin only (Fig. 4 and Fig. 5). The first roots were observed in the second week of culture on the MS medium without plant growth regulators and on the medium with $1 \mathrm{mg} \cdot \mathrm{dm}^{-3}$ NAA. At the specified auxin concentration, root formation was most intensive and proceeded until the end of the experiment. In the MS medium without NAA, the subsequent formation of roots was observed until the fifth week. Between the fifth and sixth weeks, no new root regeneration was recorded. In the seventh week, the number of roots reached the maximum number. Rhizogenesis started in the third week on explants inoculated on the MS medium with $0.5 \mathrm{mg} \cdot \mathrm{dm}^{-3} \mathrm{NAA}$, and new roots continued regenerating until Week 5 .

Only on the MS medium without plant growth regulators did we observe non-proliferation of the callus (Table 2). The share of explants regenerating calli on media with cytokinin ranged from 66.67 to $86.67 \%$, and $93.33 \%$ on the medium with $0.5 \mathrm{mg} \cdot \mathrm{dm}^{-3}$ NAAonly. On media with both auxin and cytokinin, all inoculated leaf explants formed calli. Moreover, the positive effect of a simultaneous addition of auxin and cytokinin to the media on callus formation has been recorded in gerbera 
Table 1. Share of ex vitro internodes and ex vitro leaf explants regenerating callus or adventitious shoots and the mean number of shoots in Ajania "Bengo", "Bea" and "Bess" on the modified MS (1962) medium with $3 \mathrm{mg} \cdot \mathrm{dm}^{-3} \mathrm{BAP}$ and $0.5 \mathrm{mg} \cdot \mathrm{dm}{ }^{-3} \mathrm{IAA}$

\begin{tabular}{l|l|c|c|c}
\hline \multirow{2}{*}{ Cultivar } & $\begin{array}{c}E_{X} \text { vitro } \\
\text { explant type }\end{array}$ & $\begin{array}{c}\text { Callus } \\
\text { regeneration } \\
{[\%]}\end{array}$ & $\begin{array}{c}\text { Adventitious } \\
\text { shoots } \\
\text { regeneration } \\
{[\%]}\end{array}$ & $\begin{array}{c}\text { Mean number } \\
\text { of adventitious shoots } \\
\text { per one explant } \\
\text { inoculated }\end{array}$ \\
\hline \multirow{2}{*}{ Bengo } & internode & $92.00^{\mathrm{a}}$ & $16.00^{\mathrm{a}}$ & $1.12^{\mathrm{a}}$ \\
\cline { 2 - 5 } Bea & leaf & $56.00^{\mathrm{b}}$ & $0.00^{\mathrm{b}}$ & $0.00^{\mathrm{b}}$ \\
\hline \multirow{2}{*}{ Bess } & internode & $96.00^{\mathrm{a}}$ & $4.00^{\mathrm{ab}}$ & $0.32^{\mathrm{ab}}$ \\
\cline { 2 - 5 } & leaf & $100.00^{\mathrm{a}}$ & $4.00^{\mathrm{ab}}$ & $0.20^{\mathrm{ab}}$ \\
\cline { 2 - 5 } & internode & $96.00^{\mathrm{a}}$ & $0.00^{\mathrm{b}}$ & $0.00^{\mathrm{b}}$ \\
\hline
\end{tabular}

$\mathrm{a}, \mathrm{b}-$ means in columns followed by the same letter do not differ significantly at $P=0.05$ (Tukey test)

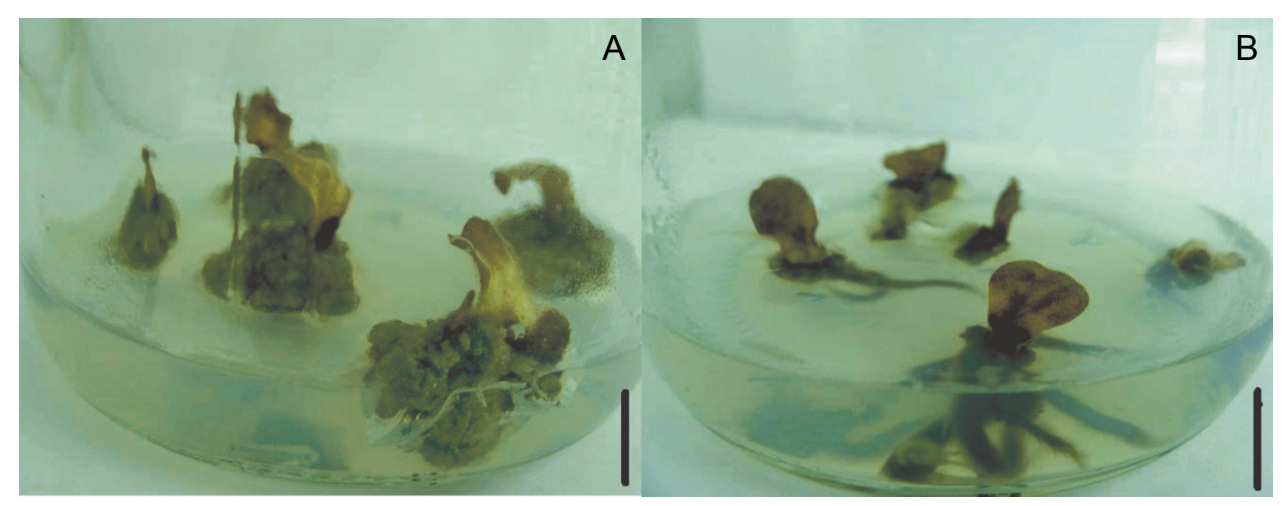

Fig. 4. Intensive regeneration of callus on the modified MS (1962) medium with $0.5 \mathrm{mg} \cdot \mathrm{dm}^{-3} \mathrm{NAA}$ and $1 \mathrm{mg} \cdot \mathrm{dm}^{-3} \mathrm{TDZ}(\mathrm{A})$ and rhizogenesis on the modified MS (1962) medium with $1 \mathrm{mg} \cdot \mathrm{dm}^{-3}$ NAA (B) in the sixth week of culture on the ex vitro leaf explants in Ajania "Silver and Gold"

$(1 \mathrm{bar}=1 \mathrm{~cm})$

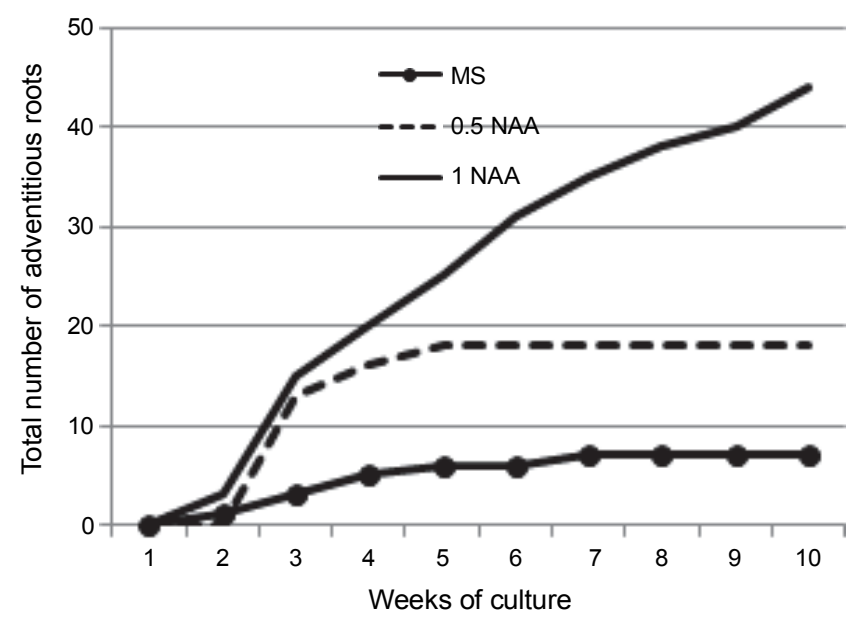

Fig. 5. Dynamics of adventitious roots regeneration on the modified MS (1962) media on the ex vitro leaf explants in Ajania "Silver and Gold"
(Kumar and Kanwar, 2005) or chrysanthemum (Tymoszuk and Zalewska, 2014a). However, in the present experiment, no regeneration of adventitious shoots was observed. The statistical analysis demonstrated that the regeneration of adventitious roots strongly depends on the qualitative and quantitative composition of the growth regulators added to the medium. Rhizogenesis occurred only on the explants inoculated on the medium without growth regulators and on the medium with 0.5 or $1 \mathrm{mg} \cdot \mathrm{dm}^{-3} \mathrm{NAA}$. In these cases, the share of regenerating explants was $40,33.33$ and $53.33 \%$, respectively. Most roots (2.93 per explant) formed on explants inoculated on the medium with the highest NAA concentration. Significantly fewer roots regenerated on the medium with $0.5 \mathrm{mg} \cdot \mathrm{dm}^{-3} \mathrm{NAA}(1.20)$ and on the medium 
Table 2. Share of ex vitro leaf explants regenerating callus or adventitious roots and the mean number of roots in Ajania "Silver and Gold" depending on the plant growth regulators added to the modified MS (1962) medium

\begin{tabular}{c|c|c|c|c|c}
\hline \multicolumn{2}{c|}{$\begin{array}{c}\text { Concentration of plant } \\
\text { growth regulators } \\
{\left[\mathrm{mg} \cdot \mathrm{dm}^{-3}\right]}\end{array}$} & $\begin{array}{c}\text { Callus } \\
\text { regeneration } \\
{[\%]}\end{array}$ & $\begin{array}{c}\text { Adventitious } \\
\text { roots } \\
\text { regeneration } \\
\text { [\%] }\end{array}$ & $\begin{array}{c}\text { Mean number } \\
\text { of adventitious roots } \\
\text { per one explant } \\
\text { inoculated }\end{array}$ \\
\hline 0 & TDZ & BAP & $0.00^{\mathrm{c}}$ & $40.00^{\mathrm{a}}$ & $0.47^{\mathrm{bc}}$ \\
\hline 0 & 0.5 & 0 & $86.67^{\mathrm{ab}}$ & $0.00^{\mathrm{b}}$ & $0.00^{\mathrm{c}}$ \\
\hline 0 & 1.0 & 0 & $80.00^{\mathrm{ab}}$ & $0.00^{\mathrm{b}}$ & $0.00^{\mathrm{c}}$ \\
\hline 0 & 0 & 0.5 & $86.67^{\mathrm{ab}}$ & $0.00^{\mathrm{b}}$ & $0.00^{\mathrm{c}}$ \\
\hline 0 & 0 & 1.0 & $66.67^{\mathrm{b}}$ & $0.00^{\mathrm{b}}$ & $0.00^{\mathrm{c}}$ \\
\hline 0.5 & 0 & 0 & $93.33^{\mathrm{ab}}$ & $33.33^{\mathrm{a}}$ & $1.20^{\mathrm{b}}$ \\
\hline 0.5 & 0.5 & 0 & $100.00^{\mathrm{a}}$ & $0.00^{\mathrm{b}}$ & $0.00^{\mathrm{c}}$ \\
\hline 0.5 & 1.0 & 0 & $100.00^{\mathrm{a}}$ & $0.00^{\mathrm{b}}$ & $0.00^{\mathrm{c}}$ \\
\hline 0.5 & 0 & 0.5 & $100.00^{\mathrm{a}}$ & $0.00^{\mathrm{b}}$ & $0.00^{\mathrm{c}}$ \\
\hline 0.5 & 0 & 1.0 & $100.00^{\mathrm{a}}$ & $0.00^{\mathrm{b}}$ & $0.00^{\mathrm{c}}$ \\
\hline 1 & 0 & 0 & $100.00^{\mathrm{a}}$ & $53.33^{\mathrm{a}}$ & $2.93^{\mathrm{a}}$ \\
\hline 1 & 0.5 & 0 & $100.00^{\mathrm{a}}$ & $0.00^{\mathrm{b}}$ & $0.00^{\mathrm{c}}$ \\
\hline 1 & 1.0 & 0 & $100.00^{\mathrm{a}}$ & $0.00^{\mathrm{b}}$ & $0.00^{\mathrm{c}}$ \\
\hline 1 & 0 & 0.5 & $100.00^{\mathrm{a}}$ & $0.00^{\mathrm{b}}$ & $0.00^{\mathrm{c}}$ \\
\hline 1 & 0 & 1 & $100.00^{\mathrm{a}}$ & $0.00^{\mathrm{b}}$ & $0.00^{\mathrm{c}}$ \\
\hline
\end{tabular}

a, b, c - means in columns followed by the same letter do not differ significantly at $P=0.05$ (Tukey test)

Table 3. Effect of Ajania cultivar on the share of ex vivo internodes regenerating callus or adventitious shoots and the mean number of shoots on the modified MS (1962) medium with $0.6 \mathrm{mg} \cdot \mathrm{dm}^{-3} \mathrm{BAP}$ and $2 \mathrm{mg} \cdot \mathrm{dm}^{-3} \mathrm{IAA}$

\begin{tabular}{l|c|c|c}
\hline Cultivar & $\begin{array}{c}\text { Callus } \\
\text { regeneration } \\
{[\%]}\end{array}$ & $\begin{array}{c}\text { Adventitious } \\
\text { shoots } \\
\text { regeneration } \\
{[\%]}\end{array}$ & $\begin{array}{c}\text { Mean number } \\
\text { of adventitious shoots } \\
\text { per one explant } \\
\text { inoculated }\end{array}$ \\
\hline Bengo & $100.00^{\mathrm{a}}$ & $50.00^{\mathrm{a}}$ & $1.30^{\mathrm{a}}$ \\
\hline Bea & $100.00^{\mathrm{a}}$ & $0.00^{\mathrm{a}}$ & $0.00^{\mathrm{b}}$ \\
\hline Bess & $100.00^{\mathrm{a}}$ & $0.00^{\mathrm{a}}$ & $0.00^{\mathrm{b}}$ \\
\hline
\end{tabular}

$\mathrm{a}, \mathrm{b}$ - means in columns followed by the same letter do not differ significantly at $P=0.05$ (Tukey test)

without plant growth regulators (0.47). A similar tendency was observed in "Brigitte" chrysanthemum. Single-node explants of this cultivar regenerated most roots on the medium without plant growth regulators as well as on the media with 1 or $2 \mathrm{mg} \cdot \mathrm{dm}^{-3}$ IAA (Kulpa et al., 2002). Kulus and Zalewska (2014) recorded a high rooting efficiency after transferring the synthetic seeds with shoot tips of four chrysanthemum cultivars to MS medium supplemented with $2 \mathrm{mg} \cdot \mathrm{dm}^{-3}$ IAA. However, synthetic seeds cultured earlier for 60 days on the recovery MS medium without plant growth regulators and on the medium with $0.1 \mathrm{mg} \cdot \mathrm{dm}^{-3} \mathrm{KIN}$ produced more roots (5.4 and 4.1 roots per explant, respectively) than the synthetic seeds on the medium with $0.1 \mathrm{mg} \cdot \mathrm{dm}^{-3}$ BAP (three roots per explant). Moreover, roots from the BAP-supplemented medium were shorter. On the other 
hand, no plant growth regulators were required to produce 100\% rhizogenesis in Kalanchoe tubiflora (Harvey) Hamet. adventitious shoots (Kulus, 2015b). Cytokinins such as BAP or TDZ act as inhibitors of rhizogenesis, which was also confirmed in our experiment. This influence depends on the cultivar as well as the type and concentration of cytokinin added to the medium. Possibly, the application of KIN, instead of BAP and TDZ, would not inhibit the rhizogenesis on Ajania leaf explants.

It is worth mentioning that roots regenerated in vitro can be used subsequently as a good source of explants for the regeneration of calli and somatic embryos, which was reported in chrysanthemum by Lema-Rumińska and coworkers (2015) and, maybe, in Ajania.

Experiment 3. Effect of cultivar on the regeneration of callus and adventitious shoots on ex vivo internodes

In the first days of culture, swelling of the whole surface of all the explants was observed, most intensively in the region of cutting. In the second week, callus regeneration began around the cutting regions. In "Bea", callus proliferation was very intensive and occurred on the whole surface of the internodes. Starting in the fourth week, there was yellowing of the callus tissue in "Bess" and "Bengo". In the third week, regeneration of adventitious shoots via callus occurred in "Bengo". In "Bea" and "Bess", no regeneration of adventitious shoots was observed (Fig. 6).

In each of the cultivars tested, all the ex vivo inoculated explants formed calli (Table 3 ); however, regeneration of adventitious shoots was only reported in Ajania "Bengo" (on $50 \%$ of inoculated ex vivo internodes). The cultivar affected the number of shoots regenerated from a single explant. One inoculated ex vivo internode in "Bengo" regenerated approximately 1.3 shoots, similarly to ex vitro internodes (1.12; Experiment 1). In Miler and Zalewska's (2014) experiment with different chrysanthemum cultivars, the efficiency of adventitious shoot regeneration per ex vitro internode on the MS medium with $0.6 \mathrm{mg} \cdot \mathrm{dm}^{-3}$ BAP and $2 \mathrm{mg} \cdot \mathrm{dm}^{-3}$ IAA ranged from 1.15 to 3.11. In the case of "Bea" cultivar, no regeneration of shoots was reported on ex vivo, compared to ex vitro, internodes. It can be assumed that ex vitro internodes are better explants for shoot regeneration than ex vivo internodes. Beck and coworkers (1998) found that the percentage of Acacia mearnsii De Wild. nodal explants producing shoots was higher when

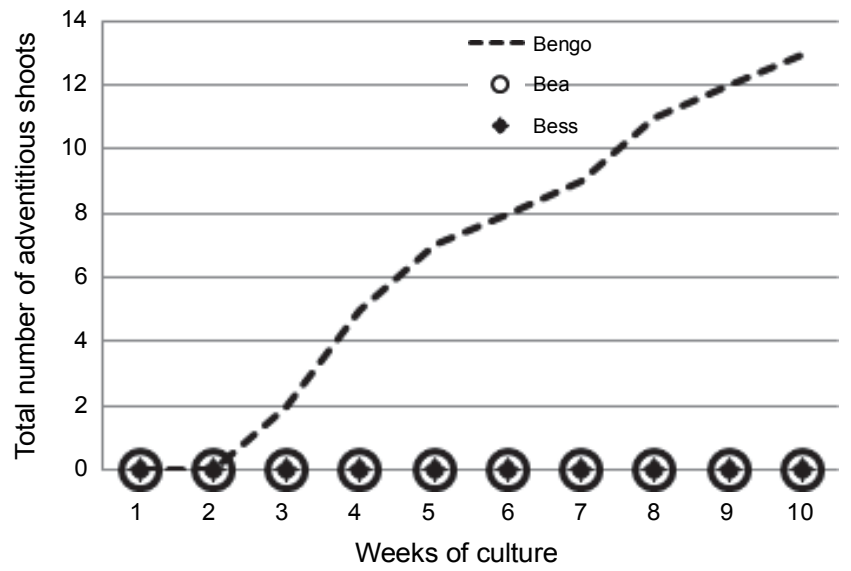

Fig. 6. Dynamics of adventitious shoots regeneration on the ex vivo internodes of Ajania "Bengo", "Bea" and "Bess" on the modified MS (1962) medium with $0.6 \mathrm{mg} \cdot \mathrm{dm}^{-3}$ BAP and $2 \mathrm{mg} \cdot \mathrm{dm}^{-3} \mathrm{IAA}$

ex vitro explants were used. Furthermore, Chakradhar and Pullaiah (2006) reported better results in Wattakaka volubilis (L.f.) Stapf axillary shoot multiplication using ex vitro nodal explants.

\section{Conclusions}

In Ajania "Bengo", "Bea" and "Bess", a high share of callus proliferation was observed on ex vitro internodes (92-96\%) and ex vitro leaf explants (56-100\%) inoculated on the modified MS medium with $3 \mathrm{mg} \cdot \mathrm{dm}^{-3}$ BAP and $0.5 \mathrm{mg} \cdot \mathrm{dm}^{-3} \mathrm{IAA}$. Adventitious shoot formation was reported on "Bengo" and "Bea" internodes (16 and 4\% explants producing shoots; 1.12 and 0.32 shoots per explant inoculated, respectively) and on "Bea" leaf explants (4\% explants producing shoots; 0.2 shoots per explant inoculated). The cultivar and explant type strongly influenced adventitious organogenesis.

Simultaneous addition of NAA auxin and TZD or BAP cytokinin at a concentration 0.5 or $1 \mathrm{mg} \cdot \mathrm{dm}^{-3}$ to the modified MS medium had a positive effect on the callogenesis of ex vitro leaf explants in Ajania "Silver and Gold". The best efficiency of adventitious roots formation was reported on the modified MS medium with $1 \mathrm{mg} \cdot \mathrm{dm}^{-3} \mathrm{NAA}$ (53.33\% explants regenerating roots and 2.93 roots per explant inoculated).

After inoculation of Ajania "Bengo", "Bea" and "Bess" ex vivo internodes on the modified MS medium supplemented with $0.6 \mathrm{mg} \cdot \mathrm{dm}^{-3}$ BAP and $2 \mathrm{mg} \cdot \mathrm{dm}^{-3}$ NAA, only the "Bengo" cultivar showed regeneration of 
adventitious shoots (50\% explants regenerating shoots and 1.3 shoots per explant inoculated). A strong influence of cultivar type on adventitious shoot formation was demonstrated. Moreover, ex vitro internodes are a better type of explants than ex vivo internodes for regeneration of adventitious shoots.

To improve the efficiency of adventitious organogenesis in Ajania, further research should be conducted on 1) the influence of the qualitative and quantitative composition of the growth regulators added to the medium, 2) other explant types (e.g. fragments of leaf blades, petals), and 3) physical factors that contribute to the maintenance of the in vitro culture (e.g. light color and intensity).

\section{References}

Beck S.L., Dunlop R., van Staden J. (1998) Micropropagation of Acacia mearnsii from ex vitro material. Plant Growth Regul. 26: 143-148.

Bremer K., Humphries C.J. (1993) Generic monograph of the Asteraceae - Anthemideae. Bull. Nat. Hist. Mus. London (Botany) 23: 71-177.

Chakradhar T., Pullaiah T. (2006) Effect of explant source on axillary shoot multiplication during micropropagation of a rare medicinal plant - Wattakaka volubilis (L.f.) Stapf. J. Plant Biochem. Biot. 15: 43-45.

Gahan P.B., George E.F. (2008) Adventitious regeneration. [in:] Plant Propagation by Tissue Culture, $3^{\text {rd }}$ ed., vol. 1: The Background. Ed. George E.F, Hall M.A., De Klerk G.J. Dordrecht: Springer: 357-391.

Hao L., Meng J.C., Cheng C.H.K., Higa T., Tanaka J., Tan R.X. (1999) New guaianolides and xanthine oxidase inhibitory flavonols from Ajania fruticulosa. J. Nat. Prod. 62(7): 1053-1055.

Jerzy M., Lubomski M. (1992) In vitro adventitious bud techniques for mutation breeding of gerbera jamesonii. Acta Hort. 314: 269-274.

Jerzy M., Zalewska M., Tymoszuk A. (2015) Effect of kinetin on the elongation of adventitious shoots regenerated in vitro from ligulate florets in Chrysanthemum $\times$ grandiflorum /Ramat./ Kitam. Acta Hort. 1083: 577-584.

Kulpa D., Rzepka-Plevnes D., Kurek J., Gacek D. (2002) Effect of hormonal composition of the media on proliferation of chrysanthemum (Dendranthema grandiflora Tzvelev) from Garden Mums'group. ZPPNR 488: 529-534 (in Polish).

Kulus D. (2014) Micropropagation of selected Agave species. PhD Interdisciplinary J. 2014(1): 75-84.

Kulus D. (2015a) Selected aspects of ornamental plants micropropagation in Poland and worldwide. Nauki Przyr. 4(10): $10-25$.

Kulus D. (2015b) Micropropagation of Kalanchoe tubiflora (Harvey) Hamet. Nauka Przyr. Technol. 9(1): 1-8.
Kulus D., Abratowska A. (2017) (CRYO)conservation of Ajania pacifica (Nakai) Bremer et Humphries shoot tips via encapsulation-dehydration technique. CryoLetters 38(5): 387-398.

Kulus D., Zalewska M. (2014) In vitro plant recovery from alginate-encapsulated Chrysanthemum $\times$ grandiflorum (Ramat.) Kitam. shoot tips. Propag. Ornam. Plants 14(1): 3-12.

Kumar S., Kanwar J.K. (2005) Plant Regeneration from callus and cell suspensions cultures of Gerbera jamesonii cv. “Diablo". Europ. J. Hort. Sci. 70(6): 265-270.

Kumar S., Kanwar J.K. (2006) Regeneration ability of petiole, leaf and petal explants in gerbera cut flower cultures in vitro. Folia Horticult. Ann. 18(2): 57-64.

Lema-Rumińska J., Kulus D. (2014) Micropropagation of cacti - a review. Haseltonia 19: 46-63.

Lema-Rumińska J., Tymoszuk A., Miler N., Durau B. (2015) Regeneration of callus from root explants of Chrysanthemum $\times$ grandiflorum (Ramat.) Kitam. ZPPNR 580: 53-61 (in Polish).

Lu Ch.-Y., Nugent G., Wardley T. (1990) Efficient, direct plant regeneration from stem segments of chrysanthemum (Chrysanthemum morifolium Ramat. cv. Royal Purple). Plant Cell Rep. 8: 773-735.

Meng J.C., Hu Y.F., Chen J.H., Tan R.X. (2001) Antifungal highly oxygenated guaianolides and other constituents from Ajania fruticulosa. Phytochemistry 58: 1141-1145.

Miler N., Zalewska M. (2014) Somaclonal variation of chrysanthemum propagated in vitro from different explants types. Acta Sci. Pol., Hortorum Cultus 13(2): 69-82.

Murashige T., Skoog F. (1962) A revised medium for rapid growth and bioassays with tobacco tissue cultures. Physiol. Plant. 15: 473-497.

Nakano M., Hoshino Y., Mii M. (1994) Adventitious shoot regeneration from cultured petal explants of carnation. Plant Cell Tiss. Org. Cult. 36: 15-19.

Park S.H., Kim G.H., Jeong B.R. (2005) Adventitious shoot regeneration in chrysanthemum as affected by plant growth regulators, sucrose, and dark period. J. Kor. Soc. Hort. Sci. 46(5): 335-340.

Park S.H., Kim G.H., Jeong B.R. (2007) Adventitious shoot regeneration from cultured petal explants of chrysanthemum. Hortic. Environ. Biotech. 48(6): 387-392.

Teixeira da Silva J.A., Kulus D. (2014) Chrysanthemum biotechnology: discoveries from the recent literature. Folia Hortic. 26(2): 67-77.

Tymoszuk A., Zalewska M. (2014a) In vitro adventitious shoots regeneration from ligulate florets in the aspect of application in chrysanthemum breeding. Acta Sci. Pol. Hort. Cultus 13(2): 45-58.

Tymoszuk A., Zalewska M. (2014b) Biological factors affecting regeneration of adventitious shoots from in vitro isolated ligulate florets of chrysanthemum. Acta Sci. Pol. Hort. Cultus 13(3): 155-165.

Zalewska M., Antkowiak M., Tymoszuk A. (2012) Micropropagation of Ajania pacifica (Nakai) Bremer et Humphries with single-node method. Nauka Przyr. Technol. 6(1): 10. 
Zalewska M., Lema-Rumińska J., Miler N. (2007) In vitro propagation using adventitious buds technique as a source of new variability in chrysanthemum. Sci. Hortic. 113: 70-73.

Zalewska M., Lema-Rumińska J., Miler N., Gruszka M., Dąbal W. (2011a) Induction of adventitious shoot regeneration in chrysanthemum as affected by the season. In Vitro Cell. Dev. Biol. - Plant 47: 375-378.

Zalewska M., Miler N., Tymoszuk A., Drzewiecka B., Winiecki J. (2010) Results of mutation breeding activity on Chry- santhemum $\times$ grandiflorum (Ramat.) Kitam. in Poland. EJAPU 13(4): 27.

Zalewska M., Tymoszuk A., Miler N. (2011b) New chrysanthemum cultivars as a result of in vitro mutagenesis with the application of different explant types. Acta Sci. Pol. Hort. Cultus 10(2): 109-123.

Zhao H., Chen F., Fang W., Guo W., Xie W. (2008) Creating novel germplasms of Chrysanthemum by employing the Ajania pacifica. Sci. Agric. Sin. 41(7): 2077-2084. 